\title{
Inter Simple Sequence Repeat Fingerprints for Assess Genetic Diversity of Tunisian Garlic Populations
}

\author{
Naouel Jabbes (Corresponding author) \\ Institut Supérieur Agronomique, Département des Sciences Horticoles et du Paysage \\ 4042 Chott Mariem, Tunisie. \\ Tel: 216-24-881-841Ｅ-mail: naouelj@yahoo.fr \\ Emmanuel Geoffriau \\ Agrocampus Ouest- Centre d'Angers, IFR QUASAV 149, UMR 1259 \\ F-49045 Angers, France \\ E-mail: emmanuel.geoffriau@inh.fr \\ Valérie Le Clerc \\ Agrocampus Ouest- Centre d'Angers, IFR QUASAV 149 \\ UMR 1259, F-49045 Angers, France \\ E-mail: valerie.leclerc@agrocampus-ouest.fr \\ Boutheina Dridi \\ Institut Supérieur d'Agronomie, Département des Sciences Horticoles et du Paysage \\ 4042 Chott Mariem, Tunisie \\ E-mail: bouthaina2@yahoo.fr \\ Chérif Hannechi \\ Institut Supérieur Agronomique, Département des Sciences Horticoles et du Paysage \\ 4042 Chott Mariem, Tunisie \\ E-mail: hannachi_tnfr@yahoo.fr
}

Received: January 26, 2011 Accepted: February 10, 2011 Published: December 1, 2011

doi:10.5539/jas.v3n4p77

URL: http://dx.doi.org/10.5539/jas.v3n4p77

\begin{abstract}
Garlic (Allium sativum L.) that is cultivated in Tunisia is heterogeneous and unclassified with no registered local cultivars. At present, the level of genetic diversity in Tunisian garlic is almost unknown. Inter Simple Sequence Repeats (ISSR) genetic markers were therefore used to assess the genetic diversity and its distribution in 31 Tunisian garlic accessions with 4 French classified clones used as control. It was the first time that ISSR markers were used to detect diversity in garlic. Seventeen ISSR primers were screened; seven primers detected 73 polymorphic bands. A high level of polymorphic loci (p) was found in Tunisian populations (54\%). Nei's total genetic diversity coefficient was 0.45 and 0.34 respectively for Tunisian and French garlic. Genetic distances observed between Tunisian accessions, ranged between 38.4 and $78.1 \%$. Factor analysis of distances' table (AFTD) did not classify accessions on the base of geographical origin or morpho-physiological characters, particularly bolting ability, but confirmed the appurtenance of analyzed accessions to sativum botanical subspecies. There was sufficient diversity detected to start a national collection of garlic germplasm which is crucial for the conservation of genetic diversity and its valorization.
\end{abstract}

Keywords: Allium sativum L., ISSR markers, Genetic diversity, Tunisian garlic populations 


\section{Introduction}

Garlic (Allium sativum L.) is a heterozygote (Satyesh, 1978) diploid specie ( $2 \mathrm{n}=16)$ (McCollum, 1987). It is generally not fertile and, thus, propagated by cloves. Etoh and Simon (2002) summarized the current classification of the Allium sativum species based on morphological, isozyme and molecular markers into four informal subspecies: the rather diverse longicuspis group including most garlic from Central Asia, the subtropical group which developed under climatic conditions of South, South East and East Asia, the ophioscorodon group from Central and East Europe; and the Mediterranean sativum group.

The sativum group, probably derived from longicuspis forms in West Asia more than 3000 years ago, has been grown in the Mediterranean area since ancient times (Etoh and Simon 2002). It has spread from there throughout the world during the last 500 years (Maab and Klaas, 1995). In fact, Mediterranean region has been postulated as the secondary center of origin of A. sativum (Etoh and Simon 2002). However, the classification of sativum taxon is still ambiguous. Messiaen et al. (1993), Pooler and Simon (1993) and Maab and Klaas (1995) declare that sativum subspecies comprises bolting and non or incomplete-bolting cultivars; whereas Engeland (1995) excludes from Allium sativum ssp sativum bolting cultivars, he classifies sativum group into two types: artichoke and silverskin. Despite a long history of obligate apomixes, cultivated garlic exhibits a large amount of morphological, physiological and bio-chemical variations (Etoh and Simon, 2002; Lallemand et al., 1997).

Genetic diversity in garlic has been studied on the basis of morphological, physiological (Messiaen et al., 1993; Burba and Riera, 1997), and isozyme markers (Pooler and Simon 1993; Maab and Klaas, 1995; Lallemand et al., 1997). However, few markers or properties are unequivocally restricted to certain types and, for most traits; interactions between genotype and environment complicate the cultivar evaluation. DNA polymorphisms are the markers of choice for identification and characterization of plants. They may be representative of the whole genome and they are not subject to environmental modification (Bachmann et al., 2001). Different molecular techniques have been developed to study garlic diversity, mostly Randomly Amplified Polymorphic DNA (RAPD) and Amplified Fragment Length Polymorphism (AFLP) (Maab and Klaas, 1995; Bradley et al., 1996; Al-Zahim et al., 1997; Ipek et al., 2003; Volk et al., 2004; Xu et al., 2005).

Inter Simple Sequence Repeat (ISSR) primers target simple sequence repeats (microsatellites) that are abundant throughout the eukaryotic genome and evolve rapidly, but they do not require prior knowledge of DNA sequence for primer design (Fang and Roose, 1997). ISSR can rapidly differentiate closely related individuals (Zietkiewicz et al., 1994) and have been successfully used to assess genetic diversity among closely related cultivars which were difficult to distinguish with other molecular marker (Fang and Roose, 1997; Dagani et al., 2003; Salhi-Hannachi et al., 2004, Salhi-Hannachi et al., 2005 and Okpul et al., 2005).

Identification of Tunisian garlic germplasm is primordial. In fact, garlic cultivated in Tunisia and in most south Mediterranean countries is botanically unclassified. Growers use their self regenerated garlic cloves and there are no local commercialized cultivars with registered names. Tunisian garlic germplasm is threatened by genetic erosion, uncontrolled introduction of foreign germplasm and under-valorization. There is little interest in collecting and studying Tunisian garlic because most local agricultural research effort is dedicated to "strategic" i.e. wheat, potato and exported crops. Although, garlic is the most expensive local vegetable in Tunisia at mid season $(5 \$ / \mathrm{kg})$ and occupies nearly $3 \%$ of the total vegetable area.

At present the variation in Tunisian garlic is almost unknown, it has not been submitted to molecular investigation. The objective of this study is to determine levels of genetic diversity and its possible structure in Tunisian garlic populations. To achieve this objective, ISSR markers were applied and their effectiveness in detecting infra population variability of garlic was also determined.

\section{Materials and methods}

\subsection{Plant material}

Thirty five garlic (Allium sativum L.) accessions were studied. Among these, 31 local landraces were collected from growers in 27 villages located in 12 provinces allover Tunisia and 4 French clones were provided by Institut National d'Horticulture et de Paysage (INHP, France). French clones were Goulurose, Messidrome, Jolimont and Germidour obtained by selection from their original populations Rose de Lautrec (RL), Blanc de la Drome (BD), Blanc de Lomagne (BL) and Violet de Cadour (VC) respectively. These selected French cultivars used as control for comparison, had registered commercial names and clear botanical classification. Tunisian collected materials were assigned accession codes. The convention adopted to assign the accession code was: letters of the original province name and range number. For example $\mathrm{JND}_{14}$ means province of Jendouba and range number is 14. Names, origins and varietal groups (according to Messiaen et al., 1993) to which the 
accessions belong to are provided in table 1 . From each accession, except one $\left(\mathrm{JND}_{13}\right)$, four individuals were randomly chosen, giving a total sampling size of 137.

\subsection{DNA extraction}

DNA was extracted from the storage leaf (excluding the bud) of 4 different bulbs from each accession. The extraction protocol is the one described by Briard et al. (2000). Quality of extracted DNA was checked on a 1\% agarose gel, then after by PCR reaction with universal primers EF1 $\alpha$, amplification products were loaded on a $2 \%$ agarose gel. The two gels were buffered with $0.5 \mathrm{x}$ TBE, stained with ethidium bromide and visualized by UV light.

\subsection{DNA amplification}

PCR reactions were performed in a $12 \mu 1$ reaction mix containing 40ng genomic DNA. Two mixtures were used for the PCR reactions according to primers (Table 2). The first one was composed of $1.5 \mathrm{mM} \mathrm{MgCl}_{2}$ (Interchim, Montluçon, France), $100 \mathrm{mM}$ of buffer (Interchim, Montluçon, France), $0.2 \mathrm{mM}$ of each dNTPs (AMRESCO Inc, Solon, Ohio, USA), $0.5 \mathrm{pmol}$ primer (EuroGentec, Angers, France) and 0.06 unit of Taq polymerase (Interchim, Montluçon, France). The second mixture consisted of $3 \mathrm{mM} \mathrm{MgCl}_{2}$ (Interchim, Montluçon, France), $100 \mathrm{mM}$ of buffer (Interchim, Montluçon, France), $0.1 \mathrm{mM}$ of each dNTPs (AMRESCO Inc, Solon, Ohio, USA), 0.8pmol primer (EuroGentec, Angers, France) and 0.1 unit of Taq polymerase (Interchim, Montluçon, France).

The mixtures were centrifuged briefly before transferring to a Peltier thermal cycler -100 (MJ research, Watertown, Massachussets, USA). The Polymerase Chain Reaction (PCR) programs consisted of 40 cycles of denaturizing at $94^{\circ} \mathrm{C}$ for $30 \mathrm{~s}$; hybridization temperature according to the used primer (Table 2), polymerization for $2 \mathrm{~min}$ at $72^{\circ} \mathrm{C}$, and the last cycle was followed by final polymerization at $72^{\circ} \mathrm{C}$ for $10 \mathrm{~min}$. The PCR products were denaturized at $92^{\circ} \mathrm{C}$ for 3 min after adding $3.8 \mu 1$ of denaturing dye to each sample and $7 \mu 1$ of denaturized PCR products were separated by electrophoresis in 5\% polyacrylamide gel with silver staining for detection.

Seventeen primers were screened using the DNA of 4 individuals resulting from 2 independent extractions and amplifications. Seven of these primers (Table 2) were selected for further testing on all 137 bulbs on the basis of clear, polymorphic and reproducible bands.

\subsection{Data analysis}

The ISSR data were recorded as the presence (1) or absence (0) of each band in each sample, so a binary data matrix was generated for all accessions. To investigate genetic diversity, proportions of ISSR loci that are polymorphic $(\mathrm{P})$ were calculated, together with total collection diversity $(\mathrm{Ht})$, diversity within accessions $(\mathrm{Hs})$ and the coefficient of genetic differentiation between accessions (Gst). The gene diversity was analyzed by Nei's (1987) coefficients using POPGEN32 software (Yeh et al. 1999).

Genetic distances between all analyzed individuals were estimated using Sokal and Michener coefficient (1958). The mean genetic distances within (IAS) and among (IES) accessions were calculated using Excel software formulae: $\Sigma \mathrm{d} / \mathrm{N}$, were $\mathrm{d}$ is the genetic distance for each pair-wise comparison and $\mathrm{N}$ is the number of pair wise comparisons (Table 3). AFTD analyses performed using Darwin 4.0 software (Perrier and Jacquemoud-Collet, 2006) on the totality of accessions. Results of this analysis are represented in figure 2.

\section{Results and discussion}

\subsection{Genetic diversity}

The seven selected ISSR primers generated 84 clear polymorphic reproducible bands. From these, 73 were chosen to be scored on the bases of their discriminate power. Indeed, markers with allelic frequency of $99 \%$ and which did not specifically distinguish accessions were eliminated to improve the discrimination between the accessions. ISSR fragments ranged from 200pb to 1300pb. Typical example of the amplified ISSR banding patterns with DNA stretches ranging from 200 to 500pb are depicted in Figure 1 using ISHY4 oligonucleotide (Table 2). Depending on the primer, 7 to 21 polymorphic bands were generated with an average of 12, which is comparable to those detected by AFLP in garlic produced from true seeds (12.8-13.9, Ipek et al., 2005) and in populations of leek (11, Smilde et al., 1999). This number of ISSR markers per primer is higher than those generated by RAPD in Brazilian and Chilean garlic (Buso et al., 2008; Paredes et al., 2008). This difference can be due mainly to the method of detection and possibly to the fact that primers are longer, and hence PCR conditions are more stringent (Godwin et al., 1997). The availability of a relatively high number of polymorphic ISSR markers reflects the heterozygous genome and that ISSR technique is able to detect as much polymorphism in a vegetative as in sexually propagated species. 
Garlic production plot is expected to be genetically invariable; however, the molecular distances existing within Tunisian accessions are high enough to be explained by the multiclonal composition of the populations (De Vos, 1992). In fact, the ISSR amplification of garlic DNA revealed a rather high degree of genetic variability among and within accessions not expected in vegetatively propagated specie. This variability is consistent with the phenotypic variability observed confirming the multiclonal composition of the analyzed landraces. Most of the primers produced a different banding pattern for each individual belonging to the same accession. Cultivar specific bands were not observed. The variation within accessions makes it difficult to define unique ISSR profiles for the groups of individuals that belong to the same landrace. The diversity within garlic populations might also be due to mutations that occurred over time due to non-reduction in grower's selection pressure (Simon and Jenderek, 2003).

The proportion of ISSR polymorphic loci (P) provided estimates of genetic diversity within accessions (Table 3). The analyzed accessions were separated into two groups: Tunisian populations group and French clones group. The mean percentage of polymorphic bands was $54.3 \%$ for Tunisian accessions, ranging from $30.1 \%\left(\mathrm{BJ}_{18}\right)$ to $75.3 \%\left(\mathrm{NB}_{25}\right)$; and $46.7 \%$ for French clones ranging from $39.7 \%(\mathrm{BD})$ to $56.1 \%$ (RL), suggesting that Tunisian populations have larger genetic diversity at the DNA level. There is reduction of diversity or variability within the process of selection through which French fixed clones were obtained, although this selection did not reduce dramatically the total diversity and with the reserve that the number of tested French clones is less then Tunisian accessions. New genotypes of garlic have not been obtained through hybridization, but through the selection of spontaneous mutations expressing traits of horticultural interest (Messiaen et al., 1993). In fact, Goulurose and Messidrome clones were isolated after multiple selections from populations of Rose de Lautrec (RL) and Blanc de la Drome (BD) respectively, whereas Jolimont and Germidour were obtained by regenerated clones of some examples from their respective initial populations Blanc de Lomagne (BL) and Violet de Cadour (VC) (Messiaen et al., 1993). They are registered clones, having certainly high degree of morphological homogeneity. At the molecular level, our study confirmed that this selection resulted in more homogeneity within French clones $(\mathrm{Hs}=0.19)$ in comparison with the diversity observed within Tunisian populations $(\mathrm{Hs}=0.22)$.

Measures of genetic diversity (Table 4) indicate that the total diversity in Tunisian garlic group $(\mathrm{Ht}=0.45)$ is higher than French one $(\mathrm{Ht}=0.34)$. Population differentiation parameters such as diversity between accessions (Gst) and diversity within accessions (Hs) showed a similar pattern across Tunisian populations and French clones, in both cases, Gst is always higher then Hs. Because of its asexual reproduction, it was expected that diversity between accessions (populations or clones) gets higher than within accessions. In terms of population genetic parameters, garlic is rather closer to a self pollinating species (Clegg and Epperson, 1992). Tunisian accessions have a higher total diversity (Ht) than French clones; it is the result of selection activities that reduced diversity in comparison with Tunisian rough material.

\subsection{Genetic distances}

According to the obtained matrix, the French accession BD (Messidrome) have the lowest genetic distance between its individuals (IAS $=21.9 \%$ ) and $\mathrm{NB}_{23}$ the highest distance (IAS=42\%) (Table 3). On the other hand, $\mathrm{JND}_{12}$ is the most genetically distant from the other materials (average of IES=48.1\%), while $\mathrm{BZT}_{26}$ is the nearest (average of IES=44.1\%). The smallest genetic distance among accessions is observed between $\mathrm{SBZ}_{3}$ and $\mathrm{SBZ}_{4}$ both from Sidi Bouzid with IES $=24.8 \%$ whereas the maximum distance of $61.6 \%$ is between $\mathrm{SBZ}_{2}$ and $\mathrm{BZT}_{27}$. Genetic distances among accessions are always higher than the distances between individuals of one accession, concordant with the observed diversity between and within accessions. The results obtained are in agreement with those reported by Lampasona et al. (2003) who found variation in Argentinean garlic clones of 24 to $97 \%$ using AFLP markers. Tunisia being in the south coast of the Mediterranean basin, great diversity in garlic germplasm is expected. Buso et al. (2008) revealed that considerable genetic variation exists among Brazilian garlic cultivars, ranging between 16 and 98\% using the RAPD markers, whereas Paredes et al. (2008) found little genetic diversity among 69 Chilean garlic clones analyzed by same markers, the percentage of the similarity ranged between 94 and $98 \%$.

The AFTD analysis, represented by figure 2, distinguishes four groups of accessions. The first one is composed of Tunisian accessions $\mathrm{SBZ}_{3,4}, \mathrm{G}_{5}, \mathrm{~KB}_{6,7,8}, \mathrm{JN}_{12}, \mathrm{BJ}_{19}$, and $\mathrm{NB}_{24}$, the second group comprises Tunisian and French accessions: $\mathrm{BD}, \mathrm{VC}, \mathrm{KF}_{31}$ and $\mathrm{MH}_{32}$. The French and Tunisian accessions RL, BL, JND $\mathrm{ND}_{13}, \mathrm{BJ}_{18}, \mathrm{NB}_{21}$ and $\mathrm{GAB}_{30}$ form the third cluster. The remaining accessions are confined in a well limited quart of the AFTD plot. Accession $\mathrm{BJ}_{17}$ does not belong to any of those groups, but seems closer to the first one. Neither our results nor the results of Ipek et al. (2003) or Paredes et al. (2008) noted an association between banding patterns and geographical origins. AFTD analysis reveals grouping that does not reflect morphological variation, or physiological characteristics, particularly the bolting character. It does not separate the bolting and not bolting accessions. This 
result suggests a common genetic basis in the implied accessions, confirming their appurtenance to the botanical taxon sativum. This thesis is strongly supported by the great similarities at the DNA level, registered between the Tunisian accessions $\mathrm{BJ}_{18}, \mathrm{NB}_{20}$ and $\mathrm{JN}_{13}$ (do not bolt) and Goulurose clone (produces flower stalk regularly), in spite of their distinctive morphology and physiology. Maab and Klaas (1995) classified four Tunisian accessions as bolting types by isozymes. Our observation of 31 Tunisian garlic accessions in-situ and in field trials for four years does not fit with this classification. In Tunisian climatic conditions, none of the accessions bolts regularly; they rather should be classified in the intermediate or non-bolting types.

\section{Conclusion}

The present results reveal that the 31 Tunisian garlic accessions analyzed are, in fact, heterogeneous but distinct populations with high level of variability within accessions that belong to sativum subspecies. The AFTD analysis did not group the Tunisian accessions according to the bolting character or the geographical origin. ISSR markers proved to be powerful tools to assess the genetic diversity among and between garlic populations and clones, but cannot define specific profile for each cultivar. It will be interesting to analyze the same accessions through the use of other molecular techniques such as AFLP to compare their effectiveness in generating cultivar-specific profiles.

The genetic variation detected in these landraces has significant implications for its characterization and classification. This study will help the start of a national collection of garlic germplasm which is crucial for the conservation of genetic diversity and its valorization.

\section{References}

Al-Zahim, M., Newbury, H.J., \& Ford-Lloyd, B.V. (1997). Classification of genetic variation in garlic (Allium sativum L.) revealed by RAPD. HortScience, 32, 1102-1104.

Bachmann, K., Blattner, F., Fischer, D., Freisen, N., Fritsch, R., Klaas, M., Mes, T., \& Pollner, S. (2001). Molecular markers in Allium: range of application, reliability and taxonomic implications. Acta Hort, 546,159-163.

Bradley, K.F., Rieger, M.A., \& Collins, G.G. (1996). Classification of Australian garlic cultivars by DNA fingerprinting. Aust. J. Exp. Agric., 36, 613-618. http://dx.doi.org/10.1071/EA9960613

Briard, M., Le Clerc, V., Grzebelus, D., Senalik, D., \& Simon, P. W. (2000). Modified protocols for rapid carrot genomic DNA extraction and AFLPtm analysis using silver stain or radioisotope. Plant Mol. Biol. Rep., 18, 235-241. http://dx.doi.org/10.1007/BF02823994

Burba, J. L., \& Riera, P. G. (1997). Characterization, adaptation and selection of garlic germplasm (Allium sativum L.) through the management of dormancy in Mendoza, Argentina. Acta Hort., 433, 151-164.

Buso, G.S.C., Paiva, M.R., Torres, A.C., Resende, F.V., Ferreira, M.A., Buso, J.A., \& Dusi, A.N. (2008). Genetic diversity studies of Brazilian garlic cultivars and quality control of garlic-clover production. Genet. Mol. Res., 7(2), 534-541. http://dx.doi.org/10.4238/vol7-2gmr451

Clegg, M. T., \& Epperson, B. K. (1992). Genetic Diversity and reproductive system. In C. D. Y. Dattée, \& A. Gallais (Eds.), Reproductive biology and plant breeding (pp. 311-323). Berlin: Springer-Verlag.

Dagani, C., Deng, J., Beiles, A., El Batsri, R., Goren, M., \& Gazit, S. (2003). Identifying Lychee (Litchi chinensis Sonn.) cultivars and their relationships using Inter simple Sequence Repeat (ISSR) markers. J.Amer.Soc.Hort.Sci., 128 (6), 838-845.

De Vos, N. E. (1992). Artichoke production in California. HortTchnology, 2, 428-444.

Etoh, T. (1985). Studies on the sterility in garlic, Allium sativum L., Mem. Fac.Agr. Kagoshima University. 21, $77-132$.

Etoh, T., \& Simon, P. W. (2002). Diversity, fertility and seed production of garlic. In H. D. Rabinovitch, \& L. Currah (Eds.), Allium crop science: Recent advances (pp. 101-117). CABI Publishing, Wallingford, UK. http://dx.doi.org/10.1079/9780851995106.0101

Fang, D. Q., \& Roose, M. L. (1997). Identification of closely related citrus cultivars with inter-simple sequence repeat markers. Theor. Appl. Genet., 95, 408-417. http://dx.doi.org/10.1007/s001220050577

Godwin, I.D., Aitken, E.A.B., \& Smith, L.W. (1997). Application of inter simple sequence repeat (ISSR) markers to plant genetics. Electrophoresis, 18, 1524-1528. http://dx.doi.org/10.1002/elps.1150180906 
Ipek, M., pek, A. I., \& Simon, P. W. (2003). Comparison of AFLPs, RAPD markers, and Isozymes for diversity assessment of garlic and detection of putative duplicates in germplasm collections. J Amer. Soc. Hort. Sci., 128 (2), 246-252.

Ipek, M., Ipek, A., Almquist, S. G., \& Simon, P.W. (2005). Demonstration of linkage and development of the first low-density genetic map of garlic, based on AFLP markers. Theor. Appl. Genet., 110, 228-236. http://dx.doi.org/10.1007/s00122-004-1815-5

Kasakova, A. A. (1978). Allium. In P. M. Zhukovsky [Eds.], Flora of cultivated plants, (vol. 10). Kolos, Leningrad.

Lallemand, J., Messian, C.M., Briand, F., \& Etoh, T. (1997). Delimitation of varietal groups in garlic (Allium sativum L.) by morphological, physiological and biochemical characters. Acta Hort., 433, 123-132.

Lampasona, S. G., Martínez, L., \& Burba, J. L. (2003). Genetic diversity among selected Argentinean garlic clones (Allium sativum L.) using AFLP (amplified fragment length polymorphism). Euphytica, 132, 115-119. http://dx.doi.org/10.1023/A:1024606004596

Maab, H. I., \& Klaas, M. (1995). Infraspecific differentiation of garlic (Allium sativum L.) by isozyme and RAPD markers. Theor. Appl. Genet., 91, 89-97.

McCollum, G.D. (1987). Onion and allies. In N.W. Simmonds (Eds.), Evolution of crop plants, (pp. 186-190). London, England.

Messiaen, C. M., Cohat, J., Leroux, J. P., Pichon, M., \& Beyries, A. (1993). Les Allium alimentaires reproduits par voie végétative. Paris, France.

Nei, M. (1987). Molecular Evolutionary Genetics. New York, USA.

Okpul, T., Mace, E. S., Godwin, I. D., Singh, D., \& Wagih, M. E. (2005). Evaluation of variability among breeding lines and cultivars of taro (Colocasia esculenta) in Papua New Guinea using ISSR fingerprinting and agro-morphological characterization. PGR Newsletter, 143, 8-16.

Paredes, C. M., V. Becerra, V., \& M. I. González, A. (2008). Low genetic diversity among garlic (Allium sativum L.) accessions detected using Random Amplified Polymorphic DNA (RAPD). Chilean J. of agric. Res., 68(1), 3-12.

Perrier, X., \& Jacquemoud-Collet, J. P. (2006). DARwin software [Online] Available: http://darwin.cirad.fr/darwin (2006).

Pooler, M. R., \& Simon, P. W. (1993). Characterization and classification of isozyme and morphological variation in a diverse collection of garlic clones. Euphytica, 68, 121-130. http://dx.doi.org/10.1007/BF00024161

Salhi-Hannachi, A., Trifi, M., Zehdi, S., Hedhfi, J., Mars, M., Rhouma, A., \& Marrakchi, M. (2004). Inter-simple sequence repeat fingerprints to access genetic diversity in Tunisian fig (Ficus carica L.) germplasm. Genet Res and Crop Evol., 51, 269-275. http://dx.doi.org/10.1023/B:GRES.0000024012.59828.6b

Salhi-Hannachi, A., Chatti, K., Mars, M., Marrakchi, M., \& Trifi, M. (2005). Comparative analysis of genetic diversity in two Tunisian collections of fig cultivars base on random amplified polymorphic DNA and inter simple sequence repeats fingerprints. Genet Res and Crop Evol., 52, 563-573. http://dx.doi.org/10.1007/s10722-003-6096-3

Satyesh, S. R. (1978). Polymorphism in giemsa banding patterns in Allium sativum. Cytologia, 43, 97-100. http://dx.doi.org/10.1508/cytologia.43.97

Simon, P. W., \& Jenderek, M. M. (2003). Flowering, seed production and the genesis of garlic breeding. Pl Breed Reviews, 23, 211-244.

Smilde, W.D., Van Heusden, A. W., \& Kik, C. (1999). AFLPs in leek (Allium porrum) are not inherited in large linkage blocks. Euphytica, 110,127-132. http://dx.doi.org/10.1023/A:1003728808682

Sokal, R. R., \& Michener, C. P. (1958). A statistical method for evaluating systematic relationships. Univ. Kan. Sci. Bul., 38, 1409-1438.

Volk, G. M., Henk, A. D., \& Richards, M. (2004). Genetic diversity among U.S garlic clones as detected using AFLP methods. J.Amer.Soc.Hort.Sci., 129 (4), 559-569.

Wolfe, A. D., Xiang, Q., \& Kephart, S. R. (1998). Assessing hybridization in natural populations of Penstemon (Scrophulariaceae) using hypervariable intersimple sequence repeat (ISSR) bands. Molecular Ecology, 7, 1107-1125. http://dx.doi.org/10.1046/j.1365-294x.1998.00425.x 
Xu, P., Chongliang, Y., Shisong, Q., \& Yang, C.Y. (2005). A preliminary study on genetic analysis and purity assessment of the garlic germplasm and seed bulbs by the "Finger Printing" technique. Acta Hort., 688: 29-33.

Yeh, F., Yang, R. C., \& Boyle, T. (1999). POPGENE Vers 1.31. Molecular Biology and Biotechnology Center, University of Alberta, Edmonton.

Zietkiewicz, E., Rafalski, A., \& Labuda, D. (1994). Genome finger-printing by simple sequence repeats (SSR)-anchored polymerase chain reaction amplification. Genomics, 20,176-183. http://dx.doi.org/10.1006/geno.1994.1151

Table 1. Garlic accessions, origins and varietal groups

\begin{tabular}{|l|c|l|l|l|c|}
\hline Code accessions*/Names & $\begin{array}{c}\text { Province of } \\
\text { origin }\end{array}$ & Source & $\begin{array}{c}\text { Country of } \\
\text { origin }\end{array}$ & $\begin{array}{l}\text { Genetic } \\
\text { structure }\end{array}$ & $\begin{array}{c}\text { Varietal } \\
\text { group** }\end{array}$ \\
\hline $\mathrm{K}_{1}$, & Kairouan & Growers & Tunisia & Population & 5 \\
$\mathrm{SBZ}_{2}, \mathrm{SBZ}_{3}, \mathrm{SBZ}_{4}, \mathrm{SBZ}_{9}$, & Sidi Bouzid & Growers & Tunisia & Population & 5 \\
$\mathrm{G}_{5}$, & Gafsa & Growers & Tunisia & Population & 5 \\
$\mathrm{~KB}_{6}, \mathrm{~KB}_{7}, \mathrm{~KB}_{8}$, & Kébili & Growers & Tunisia & Population & 5 \\
$\mathrm{KS}_{10}, \mathrm{KS}_{11}$, & Kasserine & Growers & Tunisia & Population & 5 \\
$\mathrm{JND}_{12}, \mathrm{JND}_{13}, \mathrm{JND}_{14}, \mathrm{JND}_{15}$, & Jendouba & Growers & Tunisia & Population & 5 \\
$\mathrm{BJ}_{16}, \mathrm{BJ}_{17}, \mathrm{BJ}_{18}, \mathrm{BJ}_{19}, \mathrm{BJ}_{28}$, & Béja & Growers & Tunisia & Population & 5 \\
$\mathrm{NB}_{20}, \mathrm{NB}_{21}, \mathrm{NB}_{23}, \mathrm{NB}_{24}, \mathrm{NB}_{25}$, & Nabeul & Growers & Tunisia & Population & 5 \\
$\mathrm{BZT}_{26}, \mathrm{BZT}_{27}$, & Bizerte & Growers & Tunisia & Population & 5 \\
$\mathrm{KF}_{29}, \mathrm{KF}_{31}$, & Kef & Growers & Tunisia & Population & 5 \\
$\mathrm{GAB}_{30}$, & Gabès & Growers & Tunisia & Population & 5 \\
$\mathrm{MH}_{32}$ & Mehdia & Growers & Tunisia & Population & 5 \\
\hline Violet de Cadour "Germidour" & & & & & \\
$(\mathrm{VC})$ & & INHP & France & Clone & 3 \\
\hline Blanc de la Drome & & & & \\
"Messidrome" (BD) & & INHP & France & Clone & 3 \\
\hline Blanc de Lomagne "Jolimont" & & & & \\
(BL) & & INHP & France & Clone & 3 \\
\hline Rose de Lautrec "Goulurose" & & & & \\
(RL) & & INHP & France & Clone & 2 \\
\hline
\end{tabular}

*Codes of Tunisian accessions were composed of letters and range numbers. Letters in one code were the abbreviation of original province name.

**Varietal groups according to Messiaen et al. (1993)

Table 2. ISSR primers characteristics

\begin{tabular}{|l|c|c|c|c|}
\hline $\begin{array}{c}\text { Primer } \\
\text { name }\end{array}$ & Primer sequences (5'-3') & $\begin{array}{c}\text { Annealing temperature } \\
\left({ }^{\circ} \mathrm{C}\right)\end{array}$ & Primer mixture $\mathrm{n}^{\circ}$ & $\begin{array}{c}\text { Number of } \\
\text { polymorphic } \\
\text { bands }\end{array}$ \\
\hline ISSR8US & $\mathrm{G}(\mathrm{AACA})_{4}$ & 50 & 1 & 21 \\
\hline ISSR9 & $\mathrm{HVH}(\mathrm{TC})_{8}$ & 50 & 1 & 11 \\
\hline ISHY 1b & $(\mathrm{GA})_{8} \mathrm{YT}$ & 39 & 2 & 9 \\
\hline ISHY 2 & $(\mathrm{AC}) 8 \mathrm{YG}$ & 43 & 2 & 8 \\
\hline ISHY 3 & $(\mathrm{AG}) 8 \mathrm{YT}$ & 39 & 2 & 17 \\
\hline ISHY 4 & $(\mathrm{CA}) 8 \mathrm{RG}$ & 44 & 2 & 11 \\
\hline ISSR a & $\mathrm{GCV}(\mathrm{TG}) 8$ & 51 & 2 & 7 \\
\hline Total & & \multicolumn{2}{|l}{} \\
\hline
\end{tabular}

$\mathrm{V}=\mathrm{G} ; \mathrm{A} ; \mathrm{C} \quad \mathrm{H}=\mathrm{A} ; \mathrm{T} ; \mathrm{C} \quad \mathrm{D}=\mathrm{G} ; \mathrm{A} ; \mathrm{T} \quad \mathrm{B}=\mathrm{G} ; \mathrm{C} ; \mathrm{T} \quad \mathrm{Y}=\mathrm{C} ; \mathrm{T} \quad \mathrm{R}=\mathrm{A} ; \mathrm{G}$ 
Table 3. Genetic variability detected in Tunisian and French garlic

\begin{tabular}{|c|c|c|c|}
\hline Accessions & $\mathrm{P} \%$ & IES & IAS \\
\hline K1 & 67.1 & 47 & 37.4 \\
\hline SBZ2 & 72.6 & 46.9 & 40.2 \\
\hline SBZ3 & 41.1 & 46.8 & 23.7 \\
\hline SBZ4 & 41.1 & 46.6 & 22.4 \\
\hline G5 & 59 & 47.7 & 34.2 \\
\hline KB6 & 73 & 47.4 & 40.4 \\
\hline KB7 & 61.6 & 47.2 & 34.2 \\
\hline KB8 & 49.3 & 47.1 & 28.3 \\
\hline SBZ9 & 52 & 46.4 & 30.1 \\
\hline KS10 & 45.2 & 46.9 & 26.1 \\
\hline KS11 & 65.7 & 47.7 & 37.2 \\
\hline JND12 & 50.7 & 48.1 & 29 \\
\hline JND13 & & 45.8 & \\
\hline JND14 & 73 & 46.1 & 41.8 \\
\hline JND15 & 67 & 46.1 & 39.3 \\
\hline BJ16 & 71 & 46 & 39 \\
\hline BJ17 & 49.3 & 45.3 & 32.9 \\
\hline BJ18 & 30.1 & 48 & 30.1 \\
\hline BJ19 & 58.9 & 47.4 & 32.2 \\
\hline NB20 & 49.3 & 45.5 & 32.9 \\
\hline NB21 & 53.4 & 46 & 35.6 \\
\hline NB23 & 63 & 47.2 & 42 \\
\hline NB24 & 50.7 & 47.6 & 29.2 \\
\hline NB25 & 75.3 & 45.8 & 40.6 \\
\hline BZT26 & 43.8 & 44.1 & 25.1 \\
\hline BZT27 & 46.6 & 46.4 & 25.8 \\
\hline BJ28 & 45.2 & 46.1 & 26 \\
\hline KF29 & 39.7 & 47 & 39.7 \\
\hline GAB30 & 46.6 & 46.3 & 25.6 \\
\hline KF31 & 35.6 & 45.9 & 23.7 \\
\hline MH32 & 50.7 & 44.7 & 27.9 \\
\hline RL & 56.1 & 46.7 & 31.1 \\
\hline BL & 43.8 & 45.7 & 24.9 \\
\hline $\mathrm{BD}$ & 39.7 & 45.5 & 21.9 \\
\hline $\mathrm{VC}$ & 47.3 & 46.1 & 25.3 \\
\hline
\end{tabular}

P\%: polymorphic loci, IES: mean genetic distance between accessions, IAS: genetic distance within individuals of one accession

Table 4. Partitioning of genetic diversity in Tunisian accessions and French clones

\begin{tabular}{|l|c|c|c|}
\hline Population & Ht & Hs & Gst \\
\hline Tunisien & $0,45(0.24 \%)$ & $0,22(0.5 \%)$ & 0.5 \\
\hline French & $0,34(2.2 \%)$ & $0,19(1.5 \%)$ & 0.43 \\
\hline
\end{tabular}

Ht: total diversity, Hs: diversity within accessions, Gst: diversity between accessions 


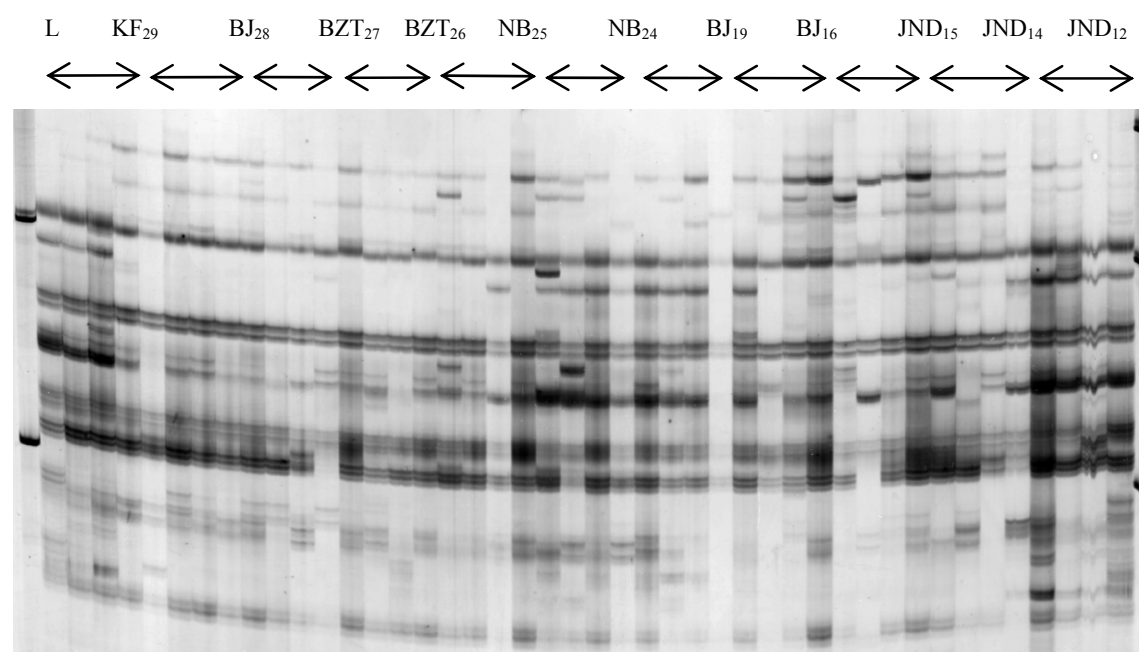

Figure 1. ISSR banding patterns of 11 garlic accessions generated by ISHY4 primer

Lanes from left to right: L: 100pb ladder, codes of the accessions with four replications for each one.

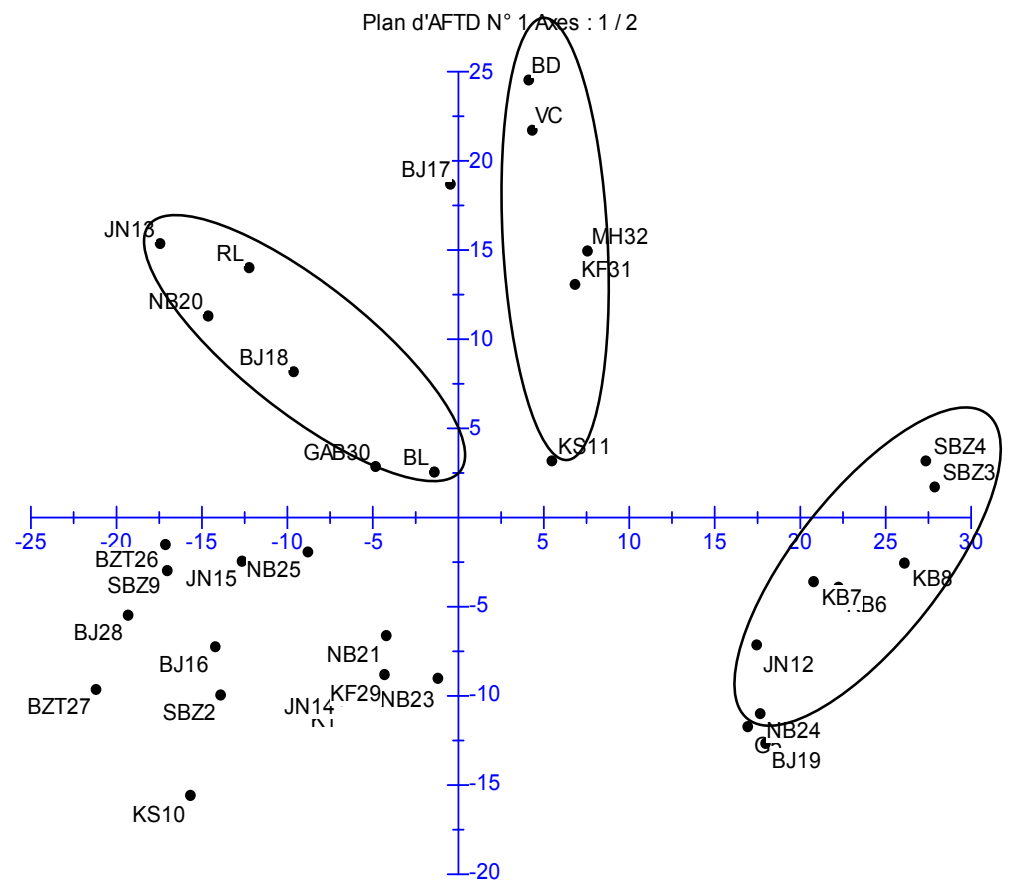

DARwin 4.0 @CIRAD-FIhor 2002 - 26-04-2008 -

Figure 2. Ordination of the first two vectors of principal coordinates analysis on ISSR molecular banding patterns between 4 French garlic clones and 31 Tunisian garlic populations 